\title{
Quality characteristics of Sulgikdduk added acorn powder
}

\author{
Sook-Yi Woo, Hyun-Suk Lee, Ju-Yeon Hong, Seung-Ryeul Shin * \\ Faculty of Herbal Food Cuisine \& Nutrition, Daegu Haany University, Kyungsan 38578, Korea
}

\section{도토리 분말을 첨가한 설기떡의 품질 특성}

\author{
우숙이 · 이현석 · 홍주연 · 신승렬 * \\ 대구한의대학교 한방식품조리영양학부
}

\begin{abstract}
The purpose of study was to evaluate quality, physicochemical and sensory characteristics of acom Sulgidduk by addition of acom powder. Acom Sulgidduk was processed rice powder which added 0, 5, 10, 15, and $20 \%$ of acom powder. The moisture, crude lipid, and crude ash contents of Sulgidduk added with acom powder was increased by addition amount of acom powder, but carbohydrate and crude protein contents were decreased. By addition amount of acom powder, soluble protein content of Sulgidduk were increased, but reducing sugar content were decreased. The $\mathrm{L}$ values of Sulgidduk were decreased by addition amount of acom powder, but increased the a and $b$ values. The hardness, adhesiveness, cohesiveness, springness and chewiness were decreased by addition amount of acom powder. The sensory test of Sulgidduk added $10 \%$ of acorn powder showed the best score in overall preference. Therefore, these results suggested that Sulgidduk added $10 \%$ of acom powder could be applied for produce of acom Sulgidduk.
\end{abstract}

Key words : acom, powder, Sulgidduk, quality characteristics, functionality

\section{서 론}

도토리(acorn)는 떡갈나무를 비롯한 졸참나무, 굴참나무, 물참나무, 갈참나무, 돌참나무 등과 같은 참나무(Genus Quercus) 열매의 총칭으로 우리나라 전국 산야에 약 28종이 자생하고 있다. 도토리는 춘궁기의 구황식품으로 오래전부 터 식용방법이 연구되었으나 근래에는 자연건강식품으로 애용되고 있다(1).

한방에서는 도토리를 가을에 열매를 딴 후 햇볕에 말려 껍질을 벗겨서 설사, 위장병에 사용한다고 하고, 민간에서 는 껍질을 달인 즙을 고환이 붓는 병과 임질 등에 사용한다 고 했으며, 위장병, 숙취, 지사작용, 잇몸질환, 강장 등의 치료제로 널리 활용되어 왔다(2). 또한 저칼로리 식품으로

*Corresponding author. E-mail : shinsr@dhu.ac.kr Phone : 82-53-819-1428, FAX : 82-53-819-1494

Received 8 April 2016; Revised 23 May 2016; Accepted 25 May 2016.

Copyright (c) The Korean Society of Food Preservation. All rights reserved.
체중감량에도 도움을 주며 당뇨 등의 성인병 예방에도 효과 가 있다(3). 도토리는 특히 폴리페놀인 탄닌과 항산화 성분 인 gallic acid, digallic acid, gallotannin 등을 다량 함유하고 있어 고지혈증이나 지방간을 예방하고 치료하는데 효과적 이며(4), 인체에 질병을 유발하는 방사성 물질인 우라늄을 제거한다는 연구결과가 있다(5)

인간의 삶의 질 향상과 식생활의 서구화로 인스턴트식품 이나 고열량, 고지방의 패스트푸드 섭취로 각종 성인병의 증가가 사회적으로 문제로 나타나면서 국민들의 건강증진 과 회복에 대한 관심이 높아지고, 노년 인구 증가로 건강기 능성 식품과 같은 건강식품에 대한 관심이 증가하고 있다. 최근의 우리나라 식생활 양식 변화로 식생활 전반에 걸친 웰빙 개념의 도입으로 떡류가 건강식품이라는 인식이 높아 지고 있어 전통 떡에 대한 관심 및 수요가 증가하고 있다 $(6,7)$. 떡은 곡물을 가루로 하여 물과 반죽하여 쪄서 만든 음식으로 정의되며, 조선시대에 이르러 떡의 종류만도 190 여종이었으며, 제조방법과 첨가 재료에 따라 찌는 떡, 치는 떡, 지지는 떡, 삶는 떡으로 구분된다. 떡은 첨가재료를 달리 할 수 있기 때문에 영양학적으로 우수한 식품일 뿐 아니라 
재료로부터 오는 색깔이나 모양도 다양해 보기에도 훌륭하 며, 생리적 기능이 있는 여러 가지 재료들을 첨가하면 건강 식품으로도 손색이 없는 고유한 전통식품이다(8,9). 설기떡 에 기능성 부재료를 첨가한 연구로는 클로렐라(10), 떫은감 분말(11), 알로에(12), 대두가루(13), 생고구마(14), 복분자 잎(15), 마분말(16) 등을 첨가하여 제조한 설기떡의 품직특 성에 관한 연구들이 보고되고 있으며, 도토리 분말을 첨가 한 설기떡의 연구는 없는 실정이다.

따라서 본 연구는 다양하고 우수한 약리활성을 가진 도 토리 분말의 첨가비율을 달리하여 도토리 설기떡을 제조한 후, 일반성분, 색도 특성, 기계적 특성과 관능적 특성을 조사 하여 도토리 설기떡의 기능성 향상과 더불어 도토리의 식품 소재로서의 활용도를 높이는데 기초자료로 활용하고자 하 였다.

\section{재료 및 방법}

\section{실험 재료}

본 연구의 주재료인 도토리는 2013년 9월에 경북 지역 일대에서 직접 채취하였으며, 도토리에 뭍은 이물질을 제 거 및 세척하였다. 도토리 분말은 분쇄기(AMS330TS, Shinil, Seoul, Korea)로 40 mesh 분쇄하여 제조하였다. 제조 된 시료는 일정량으로 분취하여 $-75^{\circ} \mathrm{C}$ deep freezer(MDFU52V, Sanyo, Osaka, Japan)에서 보관하면서 사용하였다. 도토리 분말 배합비율은 예비실험을 통하여 Table 1과 같은 기본 배합비로 하였다. 쌀(일반미, 철원), 소금(정제염, 대 상), 물(제주삼다수), 설탕(정백당, $\mathrm{CJ}$ )를 대형마트에서 구 입하여 사용하였다.

\section{설기떡의 제조}

도토리 분말을 첨가한 설기떡 제조를 위한 시료는 쌀가 루 $100 \mathrm{~g}$ 을 기준으로 설탕 $13 \%$, 소금 $1.3 \%$, 물 $15 \%$ 을 첨가 하였고, 또한 도토리 분말의 첨가량은 쌀가루 기준 0,5 , $10,15,20 \%$ 를 각각 첨가하여 제조하였다. 쌀을 씻어 12 시간 침지한 다음 쌀가루를 만들었고, 도토리분말과 소금을 혼 합하여 체에 내린 설탕을 첨가하여 제조하였다.

Table 1. Formulas for Sulgidduk added with different amounts of acorn powder

\begin{tabular}{cccccc}
\hline \multirow{2}{*}{ Ingredients (g) } & \multicolumn{5}{c}{ Rate of acorn powder (\%) } \\
\cline { 2 - 6 } & 0 & 5 & 10 & 15 & 20 \\
\hline Rice flour (g) & 200 & 190 & 180 & 170 & 160 \\
Acorn powder (g) & 0 & 10 & 20 & 30 & 40 \\
Water (g) & 60 & 60 & 60 & 60 & 60 \\
Sugar (g) & 26 & 26 & 26 & 26 & 26 \\
Salt (g) & 2.6 & 2.6 & 2.6 & 2.6 & 2.6 \\
\hline
\end{tabular}

설기떡 제조는 스텐레스 스틸 이중 찜 솥을 사용하였으 며, 틀에 면보자기를 깔고, 떡가루를 넣은 후 김이 오르고 난 후 15 분간 가열하며, 5 분간 뜸을 들였다. 찐 설기떡은 꺼내어 60 분간 방냉한 후 시료로 사용하였다.

\section{일반성분}

시료의 일반성분 분석은 $\mathrm{AOAC}$ 방법(17)에 따라 행하였 다. 즉, 수분함량은 도토리 설기떡을 일정하게 취하여 상압 건조법에 따라 측정하였고, 조단백질의 함량은 Kjeldahl 법 으로 조단백 자동분석장치(Foss Kjeltec ${ }^{\mathrm{TM}} 2300$, FOSS, Hoganas, Sweden)로 측정하였다. 조지방 함량은 Soxhlet 법에 준하여 측정하였다. 조회분 정량은 직접 회화법으로 측정하였다. 탄수화물 함량은 시료 전체 $100 \%$ 으로 하여 수분, 조단백질, 조지방, 조회분 함량을 감한 것을 탄수화물 함량(\%)으로 하였다.

\section{수용성 단백질}

도토리 설기떡의 수용성 단백질은 설기떡 $50 \mathrm{~g}$ 을 증류수 $200 \mathrm{~mL}$ 를 가하여 마쇄한 후 $3,000 \mathrm{rpm}$ 에서 10 분간 원심분 리하고 상층액만 여과지로 여과한 뒤 $250 \mathrm{~mL}$ 로 정용하였 다. 수용성 단백질의 함량은 Lowry 등의 방법(18)에 따라 측정하였다. 즉, 시료 $0.2 \mathrm{~mL}$ 를 시험관에 취하고 혼합시약 $(\mathrm{A}: \mathrm{B}=50: 1)$ 을 $1 \mathrm{~mL}$ 첨가하여 $30^{\circ} \mathrm{C}$ 에서 10 분간 반응시켰 다. 여기에 $0.1 \mathrm{~mL}$ Folin-Ciocalteu's phenol reagent를 첨가한 뒤 다시 실온에서 30 분간 반응시키고 분광광도계 (UV-2001, Hitachi, Tokyo, Japan)를 사용하여 $750 \mathrm{~nm}$ 에서 흡광도를 측정하였다. Bovine serum albumin(Sigma Chemical Co., St. Louis, MO, USA)으로 검량선을 작성하여 검량선에 의해 단백질의 함량을 산출하여 시료의 단백질 함량을 나타내었다.

\section{환원당 함량}

도토리 설기떡의 환원당 함량은 설기떡 $50 \mathrm{~g}$ 에 증류수 $200 \mathrm{~mL}$ 를 가하여 마쇄한 후 $3,000 \mathrm{rpm}$ 에서 10 분간 원심분 리하고 상층액만 여과지로 흡입하고 여과한 뒤 $250 \mathrm{~mL}$ 로 정용한 후 이것을 시료액으로 하여 Somogi-Nelson 법 (19)에 따라 측정하였다. 즉, 시료액 $1 \mathrm{~mL}$ 에 시약 $\mathrm{A}$ 액(무수 $\mathrm{Na}_{2} \mathrm{HPO}_{4} 25 \mathrm{~g}$, Rochelle염 $25 \mathrm{~g}, \mathrm{NaHCO}_{3} 20 \mathrm{~g}$, 무수 $\mathrm{Na}_{2} \mathrm{SO}_{4}$ $200 \mathrm{~g}$ 을 증류수 $1 \mathrm{~L}$ 에 용해한 액)과 시약 $\mathrm{B}$ 액 $\left(\mathrm{CuSO}_{4} \cdot 5 \mathrm{H}_{2} \mathrm{O}\right.$ $30 \mathrm{~g}$ 과 4방울의 진한 황산을 첨가한 증류수 $200 \mathrm{~mL}$ 에 용해 한 액)을 $25: 1$ 로 혼합한 액을 $0.5 \mathrm{~mL}$ 첨가하여 20 분간 가열한 뒤 냉각시켰다. 그런 다음 $\mathrm{C}$ 액(ammonium molybdate $25 \mathrm{~g}$ 을 진한 황산 $21 \mathrm{~mL}$ 를 포함하는 증류수 $450 \mathrm{~mL}$ 에 용해하고 sodium arsenate dibasic $3 \mathrm{~g}$ 을 증류수 $25 \mathrm{~mL}$ 에 용해한 후 혼합한 액)을 $1 \mathrm{~mL}$ 를 첨가해서 실온에서 방치 후 증류수 $5 \mathrm{~mL}$ 를 혼합해서 분광광도계(UV-2001, Hitachi, Tokyo, Japan)를 사용하여 $520 \mathrm{~nm}$ 에서 흡광도를 측정하였 
다. 환원당 산출은 glucose 검량선에 의해 glucose의 함량을 산출하여 환원당 함량으로 나타내었다.

\section{색도 측정}

도토리 설기떡의 색도 측정은 colormeter(CM-3600d, Minolta, Tokyo, Japan)를 사용하여 측정하였으며, 이것을 Hunter 값 즉, 명도(L, lightness), 적색도(a, redness), 황색도 (b, yellowness)로 나타내었다. 이때 사용한 표준 백색판 (standard plate)은 기기의 사용법에 따라 값을 3회 반복 측정 하였으며 평균값으로 나타내었다.

\section{조직감 측정}

도토리 설기떡의 조직감 측정은 물성측정기(COMPAC100 II, Compac, Tokyo, Japan)를 사용하여 측정하였다. 측 정조건에서 test type은 mastication test, distance $5 \mathrm{~mm}$, plunger diameter $15 \mathrm{~mm}$, adaptor type circle, table speed $60 \mathrm{~mm} / \mathrm{sec}$, load cell (max) $2 \mathrm{~kg}$ 의 조건으로 3회 반복 측정하 였다. 시료 중심부에 2 회 연속 측정하였을 때 얻어지는 값을 산출하여 경도, 부착성, 응집성, 탄력성, 씹힘성을 측정하였다.

\section{관능검사}

도토리 설기떡의 관능검사는 Park 등(20)이 행한 방법을 응용하였으며, 대학생 20 명을 관능검사원으로 선정하여 관 능검사를 실시하기 전 각각의 항목에 대해 잘 인지하도록 충분히 설명하고 훈련한 후 관능검사를 실시하였다. 관능 검사에 앞서 각 시료마다 무작위로 조합된 3자리 숫자가 주어졌으며, 시료 번호가 쓰인 접시에 담아 제시하였다. 검사 방법은 7점 척도법을 사용하고 각 평가 항목별(1점 매우 나쁘다, 2점 조금 나쁘다, 3점 나쁘다, 4점 보통, 5점 좋다 6점 조금 좋다, 7점 매우 좋다)로 평가되었다. 평가항 목은 색, 맛, 떫은 정도, 향, 질감, 전체적 기호도로 나누어 실시하였으며, 한 개의 시료를 평가 후 반드시 생수로 입안 을 헹구고 다른 시료를 평가하도록 하였다.

\section{통계처리}

$\operatorname{Park}(21)$ 의 방법을 응용하여 모든 실험은 3회 이상 반복 실시하였고, 평균 \pm 표준편차로 표시하였다. 각 실험결과는 SPSS 통계프로그램(18.0, SPSS Inc, Chicago, IL, USA)을 이용하여 일원배치 분산분석 one-way ANOVA와 Duncan's multiple range test 실시하여 $\mathrm{p}<0.05$ 에서 유의성을 검증하 고, 분석하였다.

\section{결과 및 고찰}

\section{일반성분의 변화}

도토리 분말의 첨가량을 $0,5,10,15$, 및 $20 \%$ 로 제조한
설기떡의 일반성분을 분석한 결과는 Table 2 와 같다. 도토 리 분말의 첨가량을 달리한 설기떡의 수분함량은 40.15 $44.42 \%$ 로 도토리 분말의 첨가량이 증가할수록 수분함량은 증가함을 보였고, 이는 부재료와 첨가량이 증가함에 따라 수분함량이 증가하였다는 다시마첨가 설기떡(22)과 차수 수가루 첨가 설기떡(23), 단호박 설기떡(24)의 연구와 유사 한 경향을 보였다. 탄수화물 함량은 53.48 57.63\%로 도토 리 분말 첨가량이 증가할수록 감소함을 보였고, 조단백질 의 함량은 0.75 1.24\%로 도토리 분말 첨가량이 증가할수록 감소함을 보였다. 조지방의 함량은 $0.03 ~ 0.10 \%$ 로 도토리 분말의 첨가량이 증가할수록 증가함을 보였고, 조회분의 함량은 0.95 1.24\%로 도토리 분말 첨가량이 증가할수록 증가함을 보였다. 이와 같은 결과는 도토리 분말의 첨가량 에 따른 설기떡의 일반성분 함량은 도토리 분말의 일반성분 함량에 따른 결과로 생각되어진다.

Table 2. General components content of Sulgidduk added with acorn powder

\begin{tabular}{cccccc}
\hline \multirow{2}{*}{ Components } & \multicolumn{5}{c}{ Rate of acom powder $(\%)^{1)}$} \\
\cline { 2 - 6 } & 0 & 5 & 10 & 15 & 20 \\
\hline Moisture & $40.15 \pm 0.48^{22 \times 3)}$ & $41.26 \pm 0.48^{\mathrm{d}}$ & $42.57 \pm 0.33^{\mathrm{c}}$ & $43.40 \pm 0.34^{\mathrm{b}}$ & $44.42 \pm 0.48^{\mathrm{a}}$ \\
Carbohydrate & $57.63 \pm 0.77^{\mathrm{a}}$ & $56.82 \pm 1.25^{\mathrm{a}}$ & $55.46 \pm 0.54^{\mathrm{b}}$ & $54.51 \pm 0.68^{\mathrm{bc}}$ & $53.48 \pm 0.96^{\mathrm{c}}$ \\
Crude protein & $1.24 \pm 0.26^{\mathrm{a}}$ & $0.87 \pm 0.72^{\mathrm{a}}$ & $0.80 \pm 0.17^{\mathrm{a}}$ & $0.81 \pm 0.30^{\mathrm{a}}$ & $0.75 \pm 0.44^{\mathrm{a}}$ \\
Crude lipid & $0.03 \pm 0.00^{\mathrm{e}}$ & $0.05 \pm 0.00^{\mathrm{d}}$ & $0.07 \pm 0.00^{\mathrm{c}}$ & $0.09 \pm 0.00^{\mathrm{b}}$ & $0.10 \pm 0.00^{\mathrm{a}}$ \\
Crude ash & $0.95 \pm 0.03^{\mathrm{c}}$ & $1.00 \pm 0.05^{\mathrm{c}}$ & $1.10 \pm 0.07^{\mathrm{b}}$ & $1.18 \pm 0.09^{\mathrm{a}}$ & $1.24 \pm 0.11^{\mathrm{a}}$ \\
\hline
\end{tabular}

${ }^{1)}$ Table 1. Formulas for Sulgidduk added with different amounts of acorn powder. ${ }^{2)}$ All value are expressed as Mean \pm SD of triplicate determinations.

${ }^{3}$ Different superscript letters within the same row are significantly different at $\mathrm{p}<0.05$ by Duncan's multiple range test.

\section{수용성 단백질 및 환원당 함량}

도토리 설기떡의 수용성 단백질 및 환원당 함량은 Table 3 과 같다. 도토리 분말의 첨가량을 달리한 설기떡의 수용성 단백질 함량 결과 $0.10 \sim 0.81 \mathrm{~g} / 100 \mathrm{~g}$ 로 도토리 분말의 첨가 량이 증가할수록 수용성 단백질의 함량은 증가함을 보였 다. 도토리 분말 무첨가구에서 수용성 단백질 함량이 0.10 $\mathrm{g} / 100 \mathrm{~g}$ 로 가장 낮았으며, 도토리 분말 $5 \%$ 첨가한 설기떡에 서는 $0.18 \mathrm{~g} / 100 \mathrm{~g}$, 도토리 분말 $10 \%$ 첨가한 설기떡에서는 $0.23 \mathrm{~g} / 100 \mathrm{~g}$, 도토리 분말 $15 \%$ 첨가한 설기떡에서는 0.43 $\mathrm{g} / 100 \mathrm{~g}$, 도토리 분말 $20 \%$ 첨가한 설기떡에서는 $0.81 \mathrm{~g} / 100$ $\mathrm{g}$ 으로 가장 높은 수용성 단백질 함량을 보였다.

도토리 분말의 첨가량을 달리한 설기떡의 환원당 함량 결과, $2.54 \sim 5.12 \mathrm{~g} / 100 \mathrm{~g}$ 로 도토리 분말의 첨가량이 증가할 수록 환원당 함량은 감소함을 보였다. 도토리 분말의 무첨 가구에서 환원당 함량은 $5.12 \mathrm{~g} / 100 \mathrm{~g}$ 로 가장 높았으며, 도토리 분말 $5 \%$ 첨가한 설기떡에서는 $4.85 \mathrm{~g} / 100 \mathrm{~g}$, 도토리 분말 $10 \%$ 첨가한 설기떡에서는 $4.10 \mathrm{~g} / 100 \mathrm{~g}$, 도토리 분말 $15 \%$ 첨가한 설기떡에서는 $3.81 \mathrm{~g} / 100 \mathrm{~g}$, 도토리 분말 $20 \%$ 
첨가한 설기떡에서는 $2.54 \mathrm{~g} / 100 \mathrm{~g}$ 으로 가장 낮은 환원당 함량을 보였다.

Table 3. Soluble protein and reducing sugar contents of Sulgidduk added with acorn powder

\begin{tabular}{ccc}
\hline $\begin{array}{c}\text { Rate of } \\
\text { acorn powder }(\%)^{1)}\end{array}$ & $\begin{array}{c}\text { Soluble protein } \\
(\mathrm{g} / 100 \mathrm{~g})\end{array}$ & $\begin{array}{c}\text { Reducing sugar } \\
(\mathrm{g} / 100 \mathrm{~g})\end{array}$ \\
\hline 0 & $0.10 \pm 0.00^{2) \mathrm{es}}$ & $5.12 \pm 0.00^{2) \mathrm{a} 3)}$ \\
5 & $0.18 \pm 0.00^{\mathrm{d}}$ & $4.85 \pm 0.01^{\mathrm{b}}$ \\
10 & $0.23 \pm 0.01^{\mathrm{c}}$ & $4.10 \pm 0.00^{\mathrm{c}}$ \\
15 & $0.43 \pm 0.01^{\mathrm{b}}$ & $3.81 \pm 0.00^{\mathrm{d}}$ \\
20 & $0.81 \pm 0.03^{\mathrm{a}}$ & $2.54 \pm 0.01^{\mathrm{e}}$ \\
\hline
\end{tabular}

${ }^{11)}$ Table 1. Formulas for Sulgidduk added with different amounts of acorn powder. ${ }^{2)}$ All value are expressed as Mean \pm SD of triplicate determinations.

${ }^{3}$ Different superscript letters within the same column are significantly different at $\mathrm{p}<0.05$ by Duncan's multiple range test.

\section{색 도}

도토리 분말의 첨가량을 달리하여 제조한 설기떡의 색도 측정 결과는 Table 4와 같다. 색도 측정 결과 $\mathrm{L}$ 값은 무첨가 구가 84.90로 가장 높게 나타났으며, 도토리 분말 첨가구에 서는 54.13 36.33으로 도토리 분말 첨가량이 증가할수록 명도값은 감소하는 것으로 나타났다. 이는 $\operatorname{Hwang}(25)$ 이 연구한 설기떡 제조시 분말을 포함한 다른 부재료를 첨가하 여 떡을 제조할시 첨가량이 증가할수록 $\mathrm{L}$ 값이 감소한다는 연구결과와 동일한 경향을 보였으며, 설기떡 제조시 부재 료 첨가함에 따라 멥쌀로만 만든 설기떡에 비해 $\mathrm{L}$ 값이 감소 한다는 것을 알 수 있었다. 적색도를 나타내는 a값은 도토리 분말을 첨가할수록 높게 나타나 도토리 분말 $20 \%$ 첨가한 설기떡에서 8.23 으로 높은 적색도를 보였다. 황색도를 나타 내는 b값은 무첨가구가 3.84 로 가장 낮았으며, 도토리 분말 $20 \%$ 첨가한 설기떡이 13.42 로 높게 나타나 도토리 분말 첨가량이 증가할수록 황색도는 증가하는 경향을 보였다. 이러한 결과는 Rha 등(15)이 연구한 복분자 잎 분말첨가 설기떡에서 첨가량이 증가할수록 황색도는 증가하는 결과

Table 4. Hunter's color value of Sulgidduk added with acorn powder

\begin{tabular}{cccc}
\hline \multirow{2}{*}{$\begin{array}{c}\text { Rate of } \\
\text { acom powder }(\%)^{1)}\end{array}$} & \multicolumn{3}{c}{ Hunter's color value } \\
\cline { 2 - 4 } & $\mathrm{L}$ & $\mathrm{a}$ & $\mathrm{b}$ \\
\hline 0 & $84.90 \pm 0.32^{2 \mathrm{a} a 3)}$ & $2.08 \pm 0.01^{\mathrm{d}}$ & $3.84 \pm 0.18^{\mathrm{c}}$ \\
5 & $54.13 \pm 1.02^{\mathrm{b}}$ & $6.84 \pm 0.21^{\mathrm{c}}$ & $10.92 \pm 0.74^{\mathrm{b}}$ \\
10 & $43.36 \pm 1.61^{\mathrm{c}}$ & $7.96 \pm 0.06^{\mathrm{b}}$ & $11.17 \pm 1.61^{\mathrm{b}}$ \\
15 & $36.29 \pm 1.89^{\mathrm{d}}$ & $8.03 \pm 0.22^{\mathrm{ab}}$ & $13.08 \pm 0.22^{\mathrm{a}}$ \\
20 & $36.33 \pm 1.30^{\mathrm{d}}$ & $8.23 \pm 0.03^{\mathrm{a}}$ & $13.42 \pm 0.36^{\mathrm{a}}$ \\
\hline
\end{tabular}

${ }^{1)}$ Table 1. Formulas for Sulgidduk added with different amounts of acorn powder.

${ }^{2)}$ All value are expressed as Mean $\mathrm{SD}$ of triplicate determinations.

${ }^{3)}$ Different superscript letters within the same column are significantly different at $\mathrm{p}<0.05$ by Duncan's multiple range test.
와 유사한 경향을 보였다.

\section{조직감 측정}

도토리 분말 첨가량을 달리한 설기떡의 조직감 측정 결 과는 Table 5 와 같다. 경도는 무첨가구가 $0.84 \mathrm{~kg} / \mathrm{cm}^{2}$ 으로 가장 높았으며, 도토리 분말을 첨가한 설기떡은 0.58 0.48 $\mathrm{kg} / \mathrm{cm}^{2}$ 으로 도토리 분말 첨가량이 증가할수록 경도는 감소 하는 경향을 보였다. 이러한 결과는 Yoon(26)이 연구한 연 잎가루를 첨가한 설기떡의 품질 특성 연구에서 연잎가루 첨가량이 증가할수록 경도는 낮아지는 결과와 유사한 결과 를 보여주었다. 부착성은 무첨가구에서 $38.19 \mathrm{~g}$ 으로 가장 높게 나타났고, 도토리 분말 첨가량이 증가할수록 부착성 은 감소함을 보였고, 응집성은 도토리 분말 첨가량이 증가 할수록 증가함을 보이다가 도토리 분말 첨가량 $15 \%$ 이상부 터는 감소함을 보였다. 탄력성은 도토리 분말 첨가량이 증 가할수록 높아졌으며, 도토리 분말 $20 \%$ 첨가하였을 때는 감소함을 보였다. 씹힘성은 도토리 분말 첨가량이 증가할 수록 $0.58 \sim 0.31 \mathrm{~kg}$ 으로 감소함을 보였다. 이와 같은 결과는 Kang과 $\operatorname{Kim}(27)$ 이 연구한 곰취 가루를 첨가한 설기떡의 품질특성 연구에서 곰취 가루 첨가량이 증가할수록 씹힘성 은 낮아지는 경향을 보인 결과와 유사하였다. 이러한 결과 를 종합해보면 도토리 분말의 첨가량이 증가할수록 설기떡 은 부드러운 질감을 나타내는 것을 알 수 있었다.

Table 5. Textural properties of Sulgidduk added with acorn powder

\begin{tabular}{cccccc}
\hline \multirow{2}{*}{$\begin{array}{c}\text { Rate of acomn } \\
\text { powder }(\%)^{1)}\end{array}$} & $\begin{array}{c}\text { Texture parameters } \\
\left(\mathrm{kg} / \mathrm{cm}^{2}\right)\end{array}$ & $\begin{array}{c}\text { Adhesiveness } \\
(\mathrm{g})\end{array}$ & $\begin{array}{c}\text { Cohesiveness } \\
(\%)\end{array}$ & $\begin{array}{c}\text { Springiness } \\
(\%)\end{array}$ & $\begin{array}{c}\text { Chewiness } \\
(\mathrm{kg})\end{array}$ \\
\hline 0 & $0.84 \pm 0.12^{2 \mathrm{a} 3)}$ & $38.19 \pm 3.43^{\mathrm{a}}$ & $57.94 \pm 3.94^{\mathrm{ab}}$ & $66.02 \pm 3.13^{\mathrm{c}}$ & $0.58 \pm 0.05^{\mathrm{a}}$ \\
5 & $0.58 \pm 0.09^{\mathrm{b}}$ & $23.75 \pm 9.45^{\mathrm{b}}$ & $55.55 \pm 2.03^{\mathrm{ab}}$ & $62.55 \pm 1.01^{\mathrm{c}}$ & $0.38 \pm 0.15^{\mathrm{b}}$ \\
10 & $0.57 \pm 0.07^{\mathrm{b}}$ & $25.25 \pm 4.11^{\mathrm{b}}$ & $59.01 \pm 5.70^{\mathrm{a}}$ & $70.70 \pm 1.18^{\mathrm{b}}$ & $0.36 \pm 0.06^{\mathrm{b}}$ \\
15 & $0.53 \pm 0.06^{\mathrm{b}}$ & $24.31 \pm 2.54^{\mathrm{b}}$ & $53.44 \pm 2.44^{\mathrm{ab}}$ & $78.68 \pm 2.53^{\mathrm{a}}$ & $0.31 \pm 0.03^{\mathrm{b}}$ \\
20 & $0.48 \pm 0.05^{\mathrm{b}}$ & $20.47 \pm 3.35^{\mathrm{b}}$ & $51.14 \pm 3.11^{\mathrm{b}}$ & $65.21 \pm 2.52^{\mathrm{c}}$ & $0.31 \pm 0.04^{\mathrm{b}}$ \\
\hline
\end{tabular}

${ }^{1)}$ Table 1. Formulas for Sulgidduk added with different amounts of acorn powder. ${ }^{2)}$ All value are expressed as Mean \pm SD of triplicate determinations.

${ }^{3}$ Different superscript letters within the same column are significantly different at $\mathrm{p}<0.05$ by Duncan's multiple range test.

\section{관능검사}

도토리 분말 첨가량을 달리한 설기떡의 관능검사 결과는 Table 6 과 같다. 색도는 도토리 분말 $15 \%$ 첨가한 설기떡이 6.2 로 가장 높았고, $10 \%>5 \%>20 \%>0 \%$ 순으로 평가되었 으며, 맛은 도토리 분말 $10 \%$ 첨가한 설기떡이 5.7 로 가장 높았고, 떫은 맛은 도토리 분말 $20 \%$ 첨가한 설기떡에서 가장 떫은 것으로 평가되었다. 향은 도토리 분말 $10 \%$ 첨가 한 설기떡에서 5.5 로 높았고, 도토리 분말 $15 \%$ 첨가한 설기 떡에서 5.4 로 나타났으며, 질감은 도토리 분말 $10 \%$ 첨가한 
설기떡에서 5.7 로 가장 높았고, 도토리 분말 $20 \%$ 첨가한 설기떡에서 가장 낮았다. 전반적인 기호도에서는 도토리 분말 $10 \%$ 첨가한 설기떡에서 6.3 으로 가장 높았고 $15 \%$ $>5 \%>0 \%>20 \%$ 순으로 평가되었다. 따라서 도토리 분말 $10 \%$ 첨가 설기떡이 전반적인 관능평가에서 다른 설기떡 비해 높게 평가되었으며, 설기떡 제조시 기호도 향상을 나 타낼 수 있을 것으로 판단된다.

Table 6. Sensory test of Sulgidduk added with acorn powder

\begin{tabular}{cccccc}
\hline \multirow{2}{*}{ Components } & \multicolumn{5}{c}{ Rate of acorn powder $(\%)^{1)}$} \\
\cline { 2 - 6 } & 0 & 5 & 10 & 15 & 20 \\
\hline Color & $\left.5.2 \pm 1.03^{2 \mathrm{a} a}\right)$ & $5.3 \pm 1.06^{\mathrm{a}}$ & $5.6 \pm 0.97^{\mathrm{a}}$ & $6.2 \pm 0.92^{\mathrm{a}}$ & $5.2 \pm 1.48^{\mathrm{a}}$ \\
Taste & $4.8 \pm 0.63^{\mathrm{ab}}$ & $4.9 \pm 0.99^{\mathrm{ab}}$ & $5.7 \pm 1.42^{\mathrm{a}}$ & $5.4 \pm 1.17^{\mathrm{a}}$ & $4.3 \pm 1.06^{\mathrm{b}}$ \\
Astringency & $3.1 \pm 0.32^{\mathrm{c}}$ & $4.2 \pm 0.42^{\mathrm{b}}$ & $4.8 \pm 0.79^{\mathrm{ab}}$ & $4.9 \pm 0.74^{\mathrm{ab}}$ & $5.0 \pm 1.33^{\mathrm{a}}$ \\
Flavor & $5.1 \pm 1.20^{\mathrm{a}}$ & $5.1 \pm 1.06^{\mathrm{a}}$ & $5.5 \pm 1.18^{\mathrm{a}}$ & $5.4 \pm 1.07^{\mathrm{a}}$ & $5.1 \pm 1.20^{\mathrm{a}}$ \\
Texture & $5.0 \pm 0.82^{\mathrm{ab}}$ & $5.2 \pm 1.03^{\mathrm{ab}}$ & $5.7 \pm 1.06^{\mathrm{a}}$ & $5.4 \pm 0.84^{\mathrm{ab}}$ & $4.6 \pm 0.70^{\mathrm{b}}$ \\
$\begin{array}{c}\text { Overall } \\
\text { preference }\end{array}$ & $4.8 \pm 1.23^{\mathrm{bc}}$ & $5.5 \pm 0.71^{\mathrm{abc}}$ & $6.3 \pm 0.82^{\mathrm{a}}$ & $5.7 \pm 0.95^{\mathrm{ab}}$ & $4.5 \pm 1.51^{\mathrm{c}}$ \\
\hline
\end{tabular}

${ }^{1)}$ Table 1. Formulas for Sulgidduk added with different amounts of acorn powder. ${ }^{2)}$ All value are expressed as Mean $\mathrm{SD}$ of triplicate determinations.

${ }^{3}$ Different superscript letters within the same row are significantly different at $p<0.05$ by Duncan's multiple range test.

\section{요 약}

본 연구는 쌀가루 대비 도토리 분말의 첨가량을 $0 \%, 5 \%$, $10 \%, 15 \%, 20 \%$ 로 설기떡을 제조한 후, 일반성분 함량, 수용 성 단백질, 환원당, 색도, 조직감, 관능검사 등을 실시하여 도토리 분말을 첨가한 설기떡의 품질특성을 연구하였다. 일반성분을 분석한 결과, 수분함량은 $40.15 ~ 44.42 \%$ 로 도토 리 분말의 첨가량이 증가할수록 수분함량은 증가함을 보였 고, 탄수화물 및 조단백질의 함량은 도토리 분말 첨가량이 증가할수록 감소함을 보였으며, 조지방 및 조회분 함량은 도토리 분말의 첨가량이 증가할수록 증가함을 보였다. 수 용성 단백질 함량은 $0.10 ~ 0.81 \mathrm{~g} / 100 \mathrm{~g}$ 으로 도토리 분말 무첨가구에 비해 도토리 분말 첨가량이 증가할수록 수용성 단백질 함량도 증가함을 보였고, 환원당 함량은 도토리 분 말 무첨가구에서 가장 높았고, 도토리 분말 첨가량이 증가 할수록 환원당 함량은 감소함을 보였다. 색도측정 결과 $\mathrm{L}$ 값 은 54.13 36.33으로 도토리 분말 첨가량이 증가할수록 명도 값이 감소하는 것으로 나타났고, 적색도를 나타내는 $\mathrm{a}$ 값과 황색도 $\mathrm{b}$ 값은 도토리 분말을 첨가할수록 증가하는 경향을 보였다. 조직감 측정 결과, 경도 및 씹힘성은 도토리 분말 첨가량이 증가할수록 감소하는 경향을 보였다. 관능검사 결과, 색은 도토리 분말 $15 \%$ 첨가한 설기떡이 가장 기호도 가 높았고, 맛과 향, 질감, 전반적인 기호도에서는 도토리 분말 $10 \%$ 첨가한 설기떡에서 가장 높았으며, $15 \%>5 \%>$
$0 \%>20 \%$ 순으로 평가되었다. 따라서 도토리 분말 $10 \%$ 첨가한 설기떡이 전반적인 관능평가에서 다른 첨가구에 비해 높게 평가되었으며, 설기떡 제조시 기호도 향상을 나 타낼 수 있을 것으로 판단되며, 향후 다양한 제품에 도토리 분말을 활용할 수 있을 것으로 생각된다.

\section{References}

1. Lee YM (1995) We really need to know our one hundred kinds of trees. Hyeonamsa, Seoul, Korea, p 394-398

2. Lee JM, Kim SH (2008) Antioxidant properties of acorn hot water extract using response surface methodology. Korean J Food Preserv, 15, 111-117

3. Sung IS, Kim MJ, Cho SY (1997) Effect of Quercus acutissima Carruthers extracts on the lipid metabolism. J Korean Soc Food Sci Nutr, 26, 327-333

4. Shin TH, Kim YS, Sa JH, Shin IC, Heo SI, Wang MH (2004) Studies for component analysis and antioxidative evaluation in acorn powders. Korean J Food Sci Technol, $36,800-803$

5. Kim BN (1995) A study on the literature review of acorn in korea. Korean J Food Cook Sci, 11, 158-163

6. Park ID (2008) Effects of Cucurbita maxima Duchesne puree on quality characteristics of pound and sponge cakes. Korean J Food Culture, 23, 748-754

7. Hyun YH, Hwang YK, Lee YS (2005) Quality characteristics of Sulgidduk with tapioca flour. Korean J Food Nutr, 18, 103-108

8. Ryu GH, Park JY, Koo BY, Song DS, Lim MS (2005) Korean rice cake for manufactor and process engineer. Hyoil Publishers, Seoul, p 13

9. Cha GH, Lee HG (2001) Sensory and physicochemical characteristics and storage time of Daechu-Injeulmi added with various levels of chopping jujube. Korean J Soc Food Sci, 17, 29-42

10. Park MK, Lee JM, Park CH, In MJ (2002) Quality characteristics of Sulgidduk containing chlorella powder. J Korean Soc Food Sci Nutr, 31, 225-229

11. Kim GY, Moon HK, Lee SW (2006) Quality characteristics of Sulgidduk prepared by addition of astringent persimmon powder. Korean J Food Preserv, 13, 697-702

12. Hwang SJ, Yoon SJ (2006) Quality characteristics of Sulgidduk added with aloe powder during storage. Korean J Food Cook Sci, 22, 650-658

13. Kweon SY, Kim JM, Kim JG (2007) A study on the 
quality characteristics of Sulgidduk prepared with soyflour. J East Asian Soc Dietary Life, 17, 118-124

14. Oh HE, Hong JS (2008) Quality characteristics of Sulgidduk added with fresh sweet potato. Korean J Food Cookery Sci, 24, 501-510

15. Rha YA, Kang BN (2014) Quality evaluation of Sulgidduk added with rubus coreanus miquel leaf powder. Culinary Science \& Hospitality Research, 20, 128-135

16. Kim JS, Byun GI (2009) Making fish paste with yam (Dioscorea japonica Thumb) powder and its characteristics. Culinary Science \& Hospitality Research, $15,57-69$

17. AOAC (1990) Official methods analysis 13th ed. Association of official analytical chemists. Washington DC, USA, p 125-132

18. Lowry OH, Rosebrough NJ, Farr LA, Randall RJ (1951) Protein measurement with the Folin phenol reagent. J Biol Chem, 193, 265-275

19. Nelson N (1994) A photometric adoption of the Somogi method for determination of glucose. J Biol Chem, 153, 375-381

20. Park BH, Joo HM, Cho HS (2014) Quality characteristics of dried noodles added with Ligularia fischeri powder.
Korean J Food Culture, 29, 205-211

21. Park WP (2014) Quality characteristics of noodles added with Houttuynia cordata Thunb powder. Korean J Food Preserv, 21, 34-39

22. Cho MS, Hong JS (2006) Quality characteristics of Sulgidduck by the addition of sea tangle. Korean J Food Cook Sci, 22, 37-44

23. Chae KY, Hong JS (2006) Quality characteristics of Sulgidduck with different amounts of waxy sorghum flour. Korean J Food Cook Sci, 22, 363-369

24. Yoon SJ (1999) Sensory and quality characteristics of pumpkin rice cake prepared with different amounts of pumpkin. Korean J Food Cook Sci, 15, 586-590

25. Hwang SJ (2013) Quality characteristics of Korean steamed rice cake containing different amount of red onion powder. Korean J Food Preserv, 20, 488-494

26. Yoon SJ (2007) Quality characteristics of Sulgidduk added with lotus leaf powder. Korean J Food Cook Sci, 23, 433-442

27. Kang YS, Kim JS (2011) Quality characteristics of Sulgidduk supplemented with Ligularia fischeri powder. J East Asian Soc Dietary Life, 21, 277-283 